\title{
Investigation of local scour around tandem piers for different skew-angles
}

\author{
Sargol Memar ${ }^{1, *}$, Mohammad Zounemat-Kermani ${ }^{1}$, Ali-Asghar Beheshti ${ }^{2}$, Giovanni De \\ Cesare $^{3}$, and Anton J. Schleiss ${ }^{3}$ \\ ${ }^{1}$ Department of Water Engineering, Shahid Bahonar University of Kerman, Kerman, Iran \\ Currently at: Laboratory of Hydraulic Constructions ( $\mathrm{LCH})$, Ecole Polytechnique Fédérale de \\ Lausanne (EPFL), Station 18, 1015 Lausanne, Switzerland \\ ${ }^{2}$ Water Resources Engineering Department, Ferdowsi University of Mashhad, Iran \\ ${ }^{3}$ Laboratory of Hydraulic Constructions (LCH), Ecole Polytechnique Fédérale de Lausanne (EPFL), \\ Station 18, 1015 Lausanne, Switzerland
}

\begin{abstract}
In the present study the effect of the skew-angle of the alignment of tandem piers on local scour depth around them is investigated. The tandem piers were aligned with different skew-angles of $\theta=$ $0^{\circ}, 30^{\circ}, 45^{\circ}, 60^{\circ}, 90^{\circ}$ with respect to the flow direction. The results indicate that with the increment of the skew-angle, the influence of sheltering effects is decreased. In other word, since the sheltering effect of the upstream pier is declined (which reduces the approach velocity for the downstream pier) the scour depth around downstream pier increases. The results show that the maximum scour depth occurs at both piers for the skew-angle of $\theta=45^{\circ}$. Furthermore, the best configuration to aligned tandem piers was achieved at the skew-angle of $\theta=30^{\circ}$.
\end{abstract}

\section{Introduction}

An assessment of the significance of scour phenomenon around bridge piers and abutments in rivers in order to prevent catastrophic consequences as bridge failure during floods is still a significant research question and many studies have been conducted in this scenario. Although scour is already identified as a major hazard for bridge foundations, the effect of some parameters on the scour behavior still is not very well known. The geometry of the bridge piers (shape and alignment of piers) results in different flow patterns which influences the scour depth around bridge piers. The skew-angle to the approach flow depth has a significant effect on the scour depth around bridge piers. Hence the investigation of this parameter for a more safely design of bridges is essential. Since limited studies have been carried out on the effect of the skew-angle in tandem piers [1] and [2]. In this study the

\footnotetext{
* Corresponding author: sargol.memar@epfl.ch
} 
influence of the skew-angle to the approach flow depth on the scour depth around two tandem piers was examined systematically.

\subsection{Scour mechanism around bridge piers}

The construction of bridges with their piers and abutments interacting with the river bed may influence the flow pattern around the piers and abutment regions and cause vortices. The formation of vortices is a principal mechanism of scour around bridge piers. A lot of theoretical and experimental investigations have been performed on flow characteristics around bridge piers. According to [3] downflow, horseshoe and wake vortices create the main flow structures around bridge piers. In the case of tandem piers, there are other types of vortices namely the reinforcement and sheltering vortices. The presence of the downstream pier leads to increase of the scour depth around the upstream pier by overlapping the scour holes of two piers which results in an increase of the scour depth at the upstream pier. The sheltering effect occurs when the upstream pier acts as a barrier against the approach flow toward downstream pier. Thus the strength of the downflow and horseshoe vortices around the downstream pier is decreased. For two piers in transvers arrangements except for very little spacing, each pier has his own horseshoe vortex [4] , [5].

[1] conducted experiments to investigate the effect of the skew-angle on the scour depth at two tandem piers occurring after 3 hours. The results indicated that with the smaller skewangles to the approach flow depth of $\left(0^{\circ} \leq \theta \leq 10^{\circ}\right)$, the sheltering effect from the upstream pier resulted in smaller scour depth at the downstream pier. As the skew-angle increased, the sheltering effect decreased and maximum scour depth was observed at the downstream pier. [2] accomplished experiments of 7 hours with two tandem piers with a center-to-center distance of $5 b$ between piers where $b$ is the pier diameter. In his research the values of the skew-angle was varied in the range of $\left(0^{\circ} \leq \theta \leq 90^{\circ}\right)$. The results showed the maximum scour depth occurred between $\left(30^{\circ} \leq \theta \leq 45^{\circ}\right)$ for the upstream pier and approximately $45^{\circ}$ at the downstream pier. However, it has to be noted that in the above researches the experiments lasted only a few hours without reaching the equilibrium scour depth. [6] derived an equation for estimation of the scour depth around tandem and transvers piers. The interaction of two unequal piers in tandem arrangement with different piers spacing in the clear water condition was investigated by [7]. They found that the minimum scour depth is achieved at pier spacing of $s=5 D$ which $D$ is diameter of the smaller pier. [8] studied the interference of the upstream pier on the local scour around downstream pier with two piers in tandem array and two and three piers adjusted in staggered circumstances. The results illustrated that for the tandem piers array, for the pier spacing ranges of $2 \leq s \leq 8$, the scour depth around the downstream pier has a decreasing trend with increasing pier spacing. Beyond this range the scour depth at the downstream pier is increased. Scour around bridge pier groups has been studied by different authors and some equations have been presented to estimate the scour depth [9],[10]. The HEC-18 equation is introduced by the US Federal Highway administration (FHWA) which is authentic for scour depth estimation around single and pier groups in both clear-water and live-bed conditions. In the case of pier groups, they recommended to use the effective width of an equivalent full depth pier instead of pier diameter [11]. [12] represented a correction factor for the pier groups scour using the data obtained from their research to modify the HEC-18 equation. Research on the scour depth at piers group for long time duration was done by [10]. The influence of the test duration on scour depth at pier groups was the main target of their research. Two formulations were proposed for the calculation of the piers group factor. The objective of the present study is to investigate the influence of the skew-angle on the scour depth around two tandem piers. Furthermore, the best and critical configuration of the alignment of two tandem piers were studied. The minimum and 
maximum scour depth at the upstream and downstream piers were considered in order to identify the appropriate skew-angle for building a new bridge pier alongside the old bridge at the upstream or downstream of it.

\section{Experimental procedure}

The present study was performed in the Laboratory of hydraulic construction ( $\mathrm{LCH}$ ) of Ecole Polytechnique Fédérale de Lausanne (EPFL). In order to apply the results of this study to the prototype, the design of the experiments was done taking into account the governing parameters on the scour depth around bridge piers. The most important parameters which can influence the scour depth at bridge piers are the flume width. The latter may cause a sidewall effect and results in an approach flow depth which can generates shallowness effect. In addition, the sediment size that can introduces coarseness effect [13]. The experiments were conducted in a straight flume with PVC side-walls. The length, width and height of the flume were $9 \mathrm{~m}, 1.3 \mathrm{~m}$ and $0.66 \mathrm{~m}$ respectively. Uniform quarts sand was used to fill a recess box starting at the $4 \mathrm{~m}$ from the flume entrance with $5 \mathrm{~m}$ long, $1.3 \mathrm{~m}$ width and $0.25 \mathrm{~m}$ height. The desired sediment was glued on the upstream and downstream false floors to sustain identical roughness. The piers were chosen as transparent PVC pipe with diameter of $63 \mathrm{~mm}$. In order to obtain the maximum scour depth around bridge piers for clear-water condition, the following criteria should be considered. According to [14] if $B / b \geq 10$ (where $B$ is the flume width and $b$ is the pier diameter), the side-wall effect on the scour depth around bridge piers can be neglected. In order to avoid the effect of the flow shallowness on the scour depth around bridge piers, [15] proposed to use the criterion of $h / b>2.6$ where $h$ is the approach flow depth. Quartz sand with the median sediment size of $d_{50}=1.78 \mathrm{~mm}$ and geometric standard deviation of $\sigma_{g}=1.41$ was used for the tests. The influence of the sediment size is insignificant since $b / d_{50}>25$ [15]. In addition, if the pier Reynolds number $R_{p}=U b / \vartheta>$ 7000 , the influence of the viscosity can be neglected [16]. The center-to-center distance between the piers was selected as 3 times of the pier diameter $(s=3 b)$, since according the results of the study of [8] the maximum scour depth occurred for this condition. The tandem piers were aligned with different skew-angles of $\theta=0^{\circ}, 30^{\circ}, 45^{\circ}, 60^{\circ}, 90^{\circ}$. The tests were performed with a constant discharge of $75 \mathrm{lit} / \mathrm{s}$ which was controlled with an automatically operated pump and discharge meter. The water depth was regulated by a flap gate which was installed at the downstream end of the flume. The water surface level was measured using a point gage which is installed at the upper part of the flume. In order to measure the time evolution of the scour depth in front of the piers a GoPro camera (that was able to connect to the computer) was slightly inserted into the water close to the piers front, by using a stick attached to it, and the time evolution of scour depth could be read from the glued ruler paper on the piers. Also another Go Pro camera was installed on the flume's wall to record a video of the experiment from the side view. At the end of most of the experiments the topography of the eroded bed was recorded using a three-dimensional (3D) laser Baumer, OADM $13 \mathrm{I} 7480 / \mathrm{S} 35 \mathrm{~A}$. Table 1 shows the experimental condition (the first 6 columns) as well as the dimensionless parameters of the study (the last seven columns). In Table $1, u_{C}^{*}$ is shear critical velocity and $U_{c}$ is the critical velocity. Figure 1 shows the eroded surface of the sediment bed at the end of an experiment at the equilibrium state for the skew-angle of $\theta=0^{\circ}$. In Figure 2 the contours lines of the equilibrium scour hole for the skew-angle of $\theta=0^{\circ}$ are given.

Table 1. Experimental conditions and dimensionless parameters.

\begin{tabular}{|c|c|c|c|c|c|c|c|c|c|c|c|}
\hline $\begin{array}{c}b \\
(\mathrm{~mm})\end{array}$ & $\begin{array}{c}d_{50} \\
(\mathrm{~mm})\end{array}$ & $\sigma_{g}$ & $\begin{array}{c}h \\
(\mathrm{~cm})\end{array}$ & $\begin{array}{c}U \\
(\mathrm{~cm} / \mathrm{s})\end{array}$ & $\begin{array}{c}U_{c} \\
(\mathrm{~cm} / \mathrm{s})\end{array}$ & $U / \sqrt{g h}$ & $u_{C}^{*}$ & $B / b$ & $b / d_{50}$ & $h / b$ & $R_{p}$ \\
\hline 63 & 1.78 & 1.41 & 16.5 & 0.35 & 0.42 & 0.27 & 0.03 & 10.32 & 35.4 & 2.61 & 220500 \\
\hline
\end{tabular}


The first set of the experiments were done without the presence of the piers in order to define the value of the critical velocity for onset of sediment transport. The critical velocity and shear critical velocity was also estimated by using Shields diagram and equations from different authors [17], [15], [18] ). The experimental results were in good agreement with the equation of the Shamov [17]:

$$
\frac{U_{c}}{\sqrt{g \cdot d_{50}}}=1.47\left(\frac{h}{d_{50}}\right)^{\left(\frac{1}{6}\right)}
$$
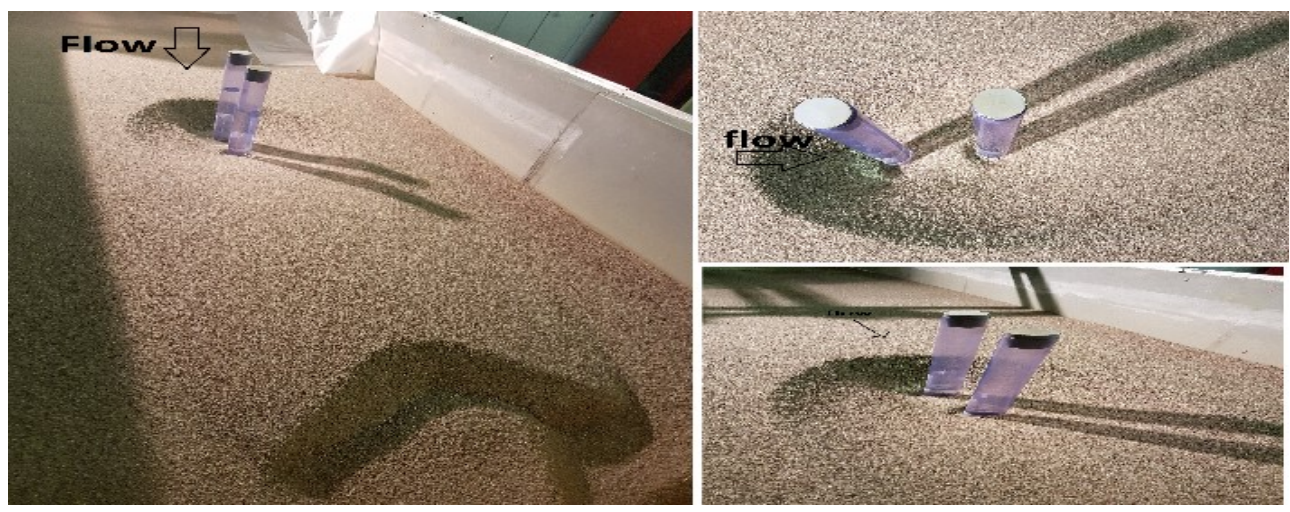

Fig. 1. Eroded sediment bed around the piers after the experiment at the equilibrium state $\left(\theta=0^{\circ}\right)$

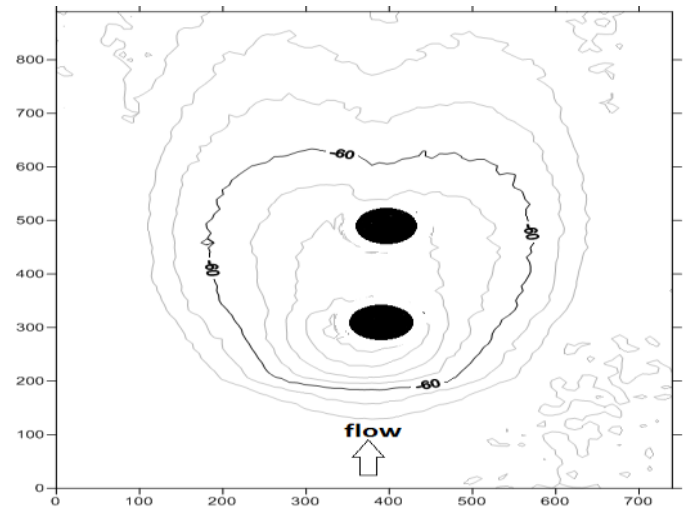

Fig. 2. Contours lines of the equilibrium scour hole for the skew-angle of $\theta=0^{\circ}$

\section{Results}

\subsection{Duration of the experiments}

In order to specify the required time to reach the equilibrium scour depth around bridge piers several criteria were suggested by different authors. Conforming to [13] if the scour depth evolution is less than $5 \%$ of the pier width in 24 hours $\left(\Delta d_{s} \leq 0.05 \mathrm{~b}\right)$, the equilibrium condition is assessed. [19] recommended a more trustworthy criterion to define the equilibrium scour depth condition. The above cited criterions were determined to detect the essential time to obtain the maximum scour depth around a single pier. In the case of group piers different flow patterns are generated due to the experiment geometry and interaction between piers. In the present study, a long duration experiment for two tandem piers with the 
skew-angle of $\theta=0^{\circ}$ was performed lasting 160 hours. Equations 2 and 3 from [13] were used to define the equilibrium time of the scour depth around piers by taking into account the effective width of an equivalent full depth pier $\left(D^{*}\right)$ to consider the piers interaction. For this purpose, the effective width of an equivalent full depth pier $\left(D^{*}\right)$ suggested by the Federal Highway Administration (FHWA) [11] was used instead of the piers width (equation 4), Where, $D_{p r o j}$ is sum of non-overlapping projected widths of piers, $K_{s p}$ is pier spacing coefficient and $K_{m}$ is number of aligned rows coefficient. The value of $D^{*}$ for the long time experiment $\left(\theta=0^{\circ}\right)$ was obtained equal to 0.069 which is bigger than the piers width.

$$
\begin{gathered}
t_{e}(\text { days })=48.26 \frac{D^{*}}{U}\left(\frac{U}{U_{C}}-0.4\right) \frac{h}{D^{*}}>6 \\
t_{e}(\text { days })=30.89 \frac{D^{*}}{U}\left(\frac{U}{U_{C}}-0.4\right)\left(\frac{h}{D^{*}}\right)^{0.25} \frac{h}{D^{*}} \leq 6 \\
D^{*}=D_{\text {proj }} * K_{s p} * K_{m}
\end{gathered}
$$

With applying the criterion of [13] the equilibrium scour depth should be achieved after almost 78 hours at the upstream pier. Nevertheless, after this time it was observed in our experiments that the scour depth still increased. Therefore the experiment was carried on until no sediment motion was observed in 24 hours around both piers. It can be concluded that the presence of the second pier and the interaction between them increased the equilibrium time to reach the maximum scour depth. Figure 3 shows the temporal evolution of the scour depth around two tandem piers with the skew-angle of $\theta=0^{\circ}$. Also the temporal evolution of the scour depth around piers was plotted in Figure 4 with the coordinates proposed by [20] described as follows [21]:

$$
\begin{gathered}
Z=\frac{d_{s}}{z_{R}} \quad, \quad Z_{R}=\left(h D^{* 2}\right)^{1 / 3} \\
T=\frac{t}{t_{R}} \quad, \quad t_{R}=\frac{Z_{R}}{\sigma^{1 / 3}\left(\Delta g d_{50}\right)^{1 / 2}}
\end{gathered}
$$

where $F_{d}=U /\left(\Delta g d_{50}\right)^{1 / 2}$ is a densimetric particle Froude number and $\Delta=\rho_{s} / \rho-1, \rho=$ water density, $\rho_{s}=$ grain density and $g=$ acceleration of gravity.$d_{s}$ is the scour depth around each pier.

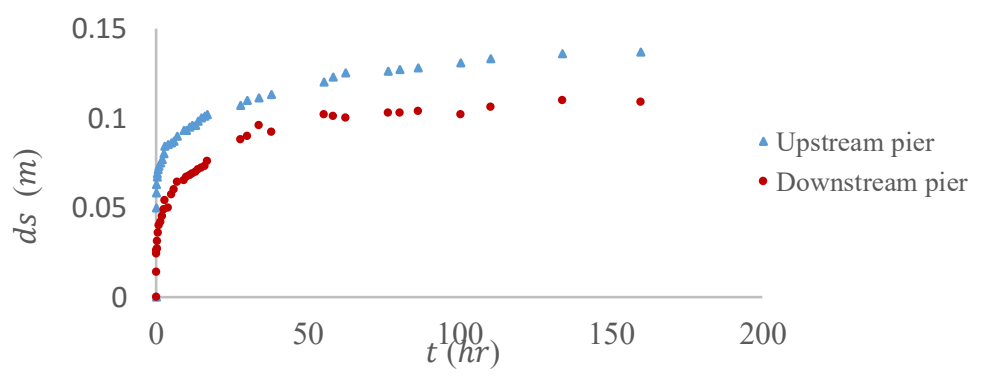

Fig. 3. Time evolution of the scour depth $d_{s}$ around tandem piers with the skew-angle of $\theta=0^{\circ}$. 


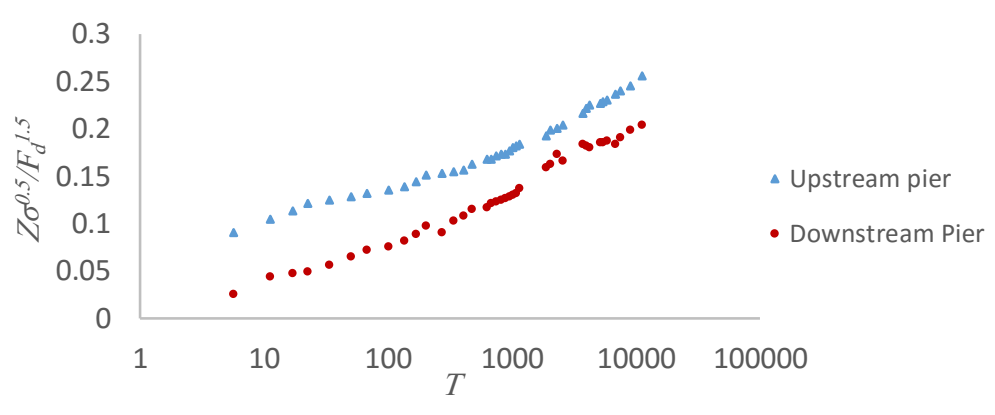

Fig. 4. Time evolution of the scour depth $d_{s}$ at tandem piers with the skew-angle of $\theta=0^{\circ}$ using coordinates of [20] in logarithmic scale.

In Figure 3 and 4 it can be seen that the scour depth at the downstream pier is about $80 \%$ of the scour depth at the upstream pier. The sheltering effect from the upstream pier decreased the approach velocity at the downstream pier. Thus the strength of the downflow and horseshoe vortices around downstream pier are declined resulting in less scour depth around downstream pier in comparison with the scour depth at the upstream pier. Figure 4 shows that the scour depth around both piers did not reach the equilibrium state. The results were then extrapolated to the infinite time by adjusting a 6 parameters polynomial function suggested by [21] to the time evolution of scour depth around each pier:

$$
d_{s}=p_{1}\left(1-\frac{1}{1+P_{1} P_{2} t}\right)+p_{3}\left(1-\frac{1}{1+P_{3} P_{4} t}\right)+p_{5}\left(1-\frac{1}{1+P_{5} P_{6} t}\right)
$$

where $d_{s}$ is a scour depth at a certain time $t$, and the parameters of $P_{1}, P_{2}, P_{3}, P_{4}, P_{5}$ and $P_{6}$ were obtained by regression analysis. At the infinite time $(t=\infty)$ the scour depth is $d_{s}=p_{1}+$ $p_{3}+p_{5}$. The other experiments were run 28 hours for the skew-angles of $\theta=30^{\circ}, 45^{\circ}, 60^{\circ}, 90^{\circ}$ hours, since it was observed that $80 \%$ of the maximum scour depth happened in the first 28 hours. The extrapolated data of the short time experiments to 160 hours are depicted in Figures 5 and 6. It can be seen that with increasing the skew-angle the maximum scour depth shifted to the downstream pier at the skew-angle of $\theta>30^{\circ}$. The maximum scour depth at both piers was observed at the skew-angle of $\theta=45^{\circ}$. For this configuration the high intensity of the interference between vortices around piers causes the maximum scour depth around both piers. At the downstream pier, the minimum scour depth was occured for $\theta=0^{\circ}$ and the maximum scour depth is observed at $\theta=45^{\circ}$ (Figure 6). As the skew-angle was increased, the protection effect and the sheltering effect from the upstream pier are reduced. At the upstream pier, the maximum and minimum scour depths were occurred for skewangles of $\theta=45^{\circ}$ and $\theta=60^{\circ}$ respectively.

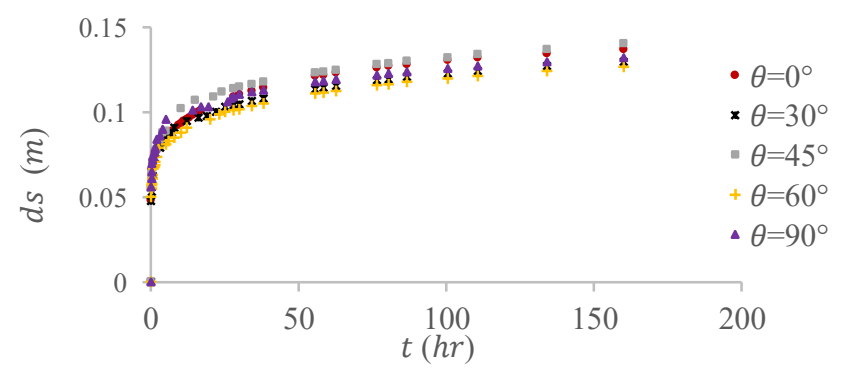

Fig. 5. Extrapolated time evolution of the scour depth $d_{s}$ around the upstream pier for different skewangles $\theta$. 


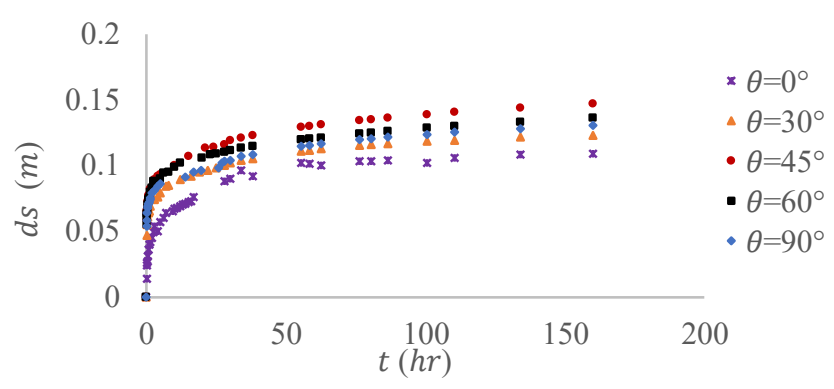

Fig. 6. Extrapolated time evolution of the scour depth $d_{s}$ around downstream pier for different skewangles $\theta$.

In Figure 7 the effect of the skew-angle on scour depth at both piers can be seen. The results of this study were compared with the results of [2]. For the upstream pier, the maximum scour depth was occurred at $\theta=45^{\circ}$, from this it can be concluded that the interference of vortices around the piers is higher than the other cases. Furthermore, comparing $\theta=0^{\circ}$ and $\theta=30^{\circ}$, shows small discrepancy in scour depth at the upstream pier, although the scour depth is greater for $\theta=0^{\circ}$. This might be due to diminishing the sheltering effect by increasing the skew-angle. In both studies the critical piers configuration, which caused the maximum scour depth at both piers, was observed for a skew-angle of $\theta=45^{\circ}$. At the downstream pier the minimum scour depth was observed for a skew-angle of $\theta=0^{\circ}$. The difference between the values of the dimensionless scour depth can be explained by the short time duration of the scour depth in the study of [2] since the equilibrium scour depth was not achieved. $d_{s 1}$ is a scour depth at a single pier. The best configuration for the alignment of tandem piers respect to the approach flow depth was obtained for the skew-angle of $\theta=30^{\circ}$ in the present study. However the results of [2] showed the best arrangement for a skewangle of $\theta=0^{\circ}$. This discrepancy can be explained by the difference of the piers spacing in both studies. The experiments by [2] were performed in the higher pier spacing $(s=5 b)$. Therefore the interaction between piers and the sheltering effect from the upstream pier are smaller than that in the present study. In Table 2 the percentage of decreasing or increasing of the scour depth values relative to the scour depth at the skew-angle of $\theta=0^{\circ}$ are given for upstream pier $\left(r_{1} \%\right)$ and for the downstream pier $\left(r_{2} \%\right)$. Positive values shows the increase in scour depth whereas the negative values shows the decrease in scour depth. Table 2 gives the equilibrium scour depth $D_{s 1}, D_{s 2}$ at the infinite time $(t=\infty)$, for the upstream and the downstream piers respectively, obtained by adapting Equation 6 to time evolution of the scour depth curve in each experiment.

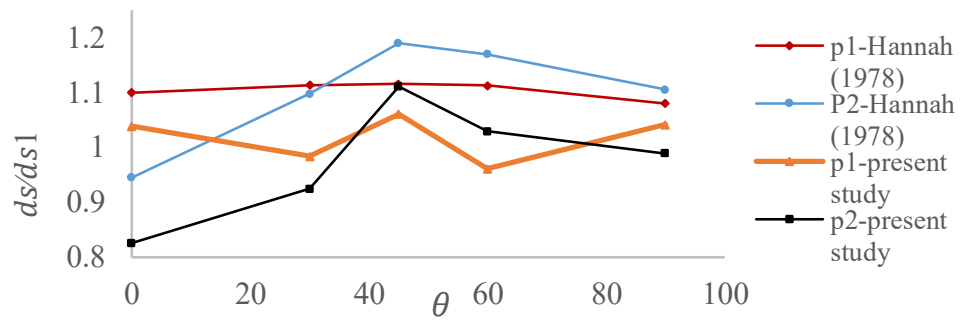

Fig. 7. Effect of the skew-angle on the scour depth at tandem piers 
Table 2. Effect of the skew-angle on the scour depth at tandem piers

\begin{tabular}{|c|c|c|c|c|}
\hline$\theta$ & $D_{s 1}$ & $D_{s 2}$ & $r_{1} \%$ & $r_{2} \%$ \\
\hline 0 & 15.34 & 11.75 & 0 & 0 \\
\hline 30 & 15.1 & 13.57 & -1.56 & 13.41 \\
\hline 45 & 17.09 & 18.67 & 10.23 & 37.06 \\
\hline 60 & 14.84 & 17.14 & -3.25 & 31.44 \\
\hline 90 & 16.35 & 15.18 & 6.17 & 22.59 \\
\hline
\end{tabular}

\section{Conclusions}

In the present study, the effect of the skew-angle on the scour depth at two tandem piers was investigated. The results show that the best piers configuration for the tandem piers occurs at a skew-angle of $\theta=30^{\circ}$. Furthermore, the critical skew-angle, for which the maximum scour depth at both piers occurred, is $\theta=45^{\circ}$.

The result showed that the minimum scour depth at downstream pier is obtained for a skew-angle of $\theta=0^{\circ}$ since the upstream pier has a maximum protection effect for the downstream pier by reducing the approach velocity towards the downstream pier. $60^{\circ}$.

At the upstream pier, the minimum scour depth was observed at the skew angle of $\theta=$

\section{References}

[1] E.M. Laursen, A. Toch, Iowa Highway Research Board, 4 (1956).

[2] C.R. Hannah, Canterbury Univ., Canterbury, New Zealand, (1978).

[3] W.H. Graf, I. Istiarto, J. Hydraul. Res. 40, 13-20 (2002).

[4] R. Ettema, B. Melville, G. Constantinescu, Washington, DC: Transportation Research Board of the National Academies (2011).

[5] A. R. Zarrati, M. Nazariha, M.B. Mashahir, J. Hydraul. Eng. 132, 154-162 (2006).

[6] K.R. Elliott, C.J. Baker, J. Hydraul. Eng. 111, 1105-1109 (1985).

[7] M. Beg, S. Beg, ISH. J. Hydraul. Eng. 21, 85-96 (2015).

[8] S. Khaple, P.R. Hanmaiahgari, R. Gaudio, S. Dey, Acta Geophys. 65, 29-46 (2017).

[9] A.A. Beheshti, B. Ataie-Ashtiani, Ocean Eng. 123, 249-252 (2016).

[10] R. Lanca, C. Fael, R. Maia, J.P. Pego, A.H. Cardoso, J. Hydraul. Eng. 139, 10891098 (2013).

[11] S.R.D. E.V. Richardson, Hydraul. Eng. Circ. No. 18 (HEC-18), Rep. No. FHwA. NHI 01-001, Fed. Highw. Adm. Washington, D.C. (2001).

[12] B. Ataie-Ashtiani, A.A. Beheshti, J. Hydraul. Eng. 132, 1100-1104 (2006).

[13] B.W. Melville, Y. Chiew, J. Hydraul. Eng. 125, 59-65 (1999).

[14] Y.M. Chiew, B.W. Melville, J. Hydraul. Res. 25, 15-26 (1987).

[15] B.W. Melville, A.J. Sutherland, J. Hydraul. Eng. 114, 1210-1226 (1988).

[16] R. Monti, Polytechnic of Milan, Milan, Italy (in Italian) (1994).

[17] S. Dey, Fluvial Hydrodynamics, (2014).

[18] D.M. Sheppard, B. Melville, H. Demir, J. Hydraul. Eng. 140, 14-23 (2014).

[19] C. Grimaldi, R. Gaudio, F. Calomino, A.H. Cardoso, J. Hydraul. Eng. 135, 13-21 (2009).

[20] G. Oliveto, W.H. Hager, J. Hydraul. Eng. 128, 811-820 (2002).

[21] R. Lança, C. Fael, A. Cardoso, River Flow 2010, 1207-1213 (2010). 